\title{
The Divergence Between Prophet's Masjid and Present Masjid: an Architectural Essay
}

\author{
Deni*, Bambang Karsono, Rinaldi Mirsa, Adi Safyan, Eri Saputra \\ Department of Architectural Engineering, Universitas Malikussaleh, Aceh, Indonesia \\ *Corresponding authorE-mail: deni@unimal.ac.id
}

Manuscript received 23 Feb 2021; revised 2 March. 2021; accepted 15 March 2021. Date of publication 2 April 2021

\begin{abstract}
Basically, functional aspect in masjid can easily understand that there are divergence phenomena between the present masjid compared to the physical appearance and function of the Prophet's Masjid in the beginning. The objective of study is to reveals the existence of the Prophet's Masjid regarding the process and physical description of the masjid through hadith, sirah nabawiyah and related references as a guideline for comparative thinking on the present masjid. Critical descriptive research method is used as an analytical instrument to assess present masjid by adopting the idea of function in architecture knowledge and collaborate with the idea of social values as a reflection of the paradigm of Muslims towards the present masjid. Discussion find out that the people's perspective on present masjid tends to be statically trapped in the shape, form and visuals from the legacy of Islamic civilization after the time of the Prophet's Muhammad PBUH.
\end{abstract}

Keywords: Divergence, Present Masjid, Prophet's Masjid.

\section{Introduction}

Masjids are a place of worship for Muslims in all around of the world. The physical and social existences of masjid observed have been generated base on different approaches, depend on the perception, perspective, and paradigm of local Muslims people. Moderately the existences of present mosques have become diverse and deep-rooted to such culture. Most of the present mosque designs are still trapped in the precedent of design approach based on Islamic civilization, which usually presenting the grand scale building with very expensive construction costs [1].

Referring to the life history of the Prophet Muhammad PBUH or Sirah Nabawiyah, clarify that the mosque is not only function as a place to perform prayers (solah) alone, but also as a school (madrasah) for Muslims to obtain Islamic thought, as a place to manage and taking care of the people needs for their social life and concurrently function as a government building. The embodiment of Islamic thought faultlessly implemented in Prophet's Masjid during the time [2].

In the present time, masjid as superlative objects have divergences in the way how do people design and utilize it, compared to masjid during Prophet era's. The space in masjid tend to turn into an exclusive space just for solah, tausiyah and other ritual activities. It describes that the value of a masjid which exemplified by Prophet Muhammad PBUH going to decline. Behave from this phenomena, the only way back to find the original value of masjid are by referring to Qur'an and Hadith. Architectural knowledge can be a supplementary instrument to reveal the past and original space arrangement, structure and aesthetic value along with activities. Parallel to that, the study on the existence of the present masjid need to carried out as an effort to approaching the reflection of the past Prophet's Masjid in a way to restoring the Muslim point of view regarding the understanding of masjid itself.

This research was inspired by the term ascesis as "an exercise of oneself" [5] [6], the aim is to study how deep the history itself provides freedom of thought that allows someone to think differently. There are two major questions to be answered in this study, firstly, according to the Sirah Nabawiyah, it is stated that Islam is the last heavenly religion that came from God to the last Prophet Muhammad PBUH as the most perfect and complete religion ever. However, in present masjid, the embodiment of perfection itself is look to be limited as a place for rituals only. Secondly, is the visual luxury can improve the quality of life of the Muslims based on the dogmatic agreement of Islamic thought on the presence of the masjid as the center of people's lives. These two questions are really important in an attempt to reveal the phenomena of present masjid. The focus of discussion is not looking on the process of design and construction of present masjid, but more on the discussion of the usage of space in the masjid as critical topic that defines the field of practice. 